\title{
Notes
}

\section{From "Cooperator's Loss" to Cooperative Gain: Negotiating Greenhouse Gas Abatement}

\author{
Adam L. Aronson
}

\section{INTRODUCTION}

Greenhouse gas abatement has proved to be among the most difficult environmental issues on which to negotiate global agreement. ${ }^{1}$ The Convention on Climate Change, presented for signature at the United Nations Conference on the Environment and Development in Rio de Janeiro in June of 1992 , took fifteen months to prepare. ${ }^{2}$ The final document was so watered down, primarily at the insistence of the U.S., that it provided neither specific timetables nor targets for limiting emissions of greenhouse gases (GHG's) by industrialized countries. ${ }^{3}$ The Climate Convention hence provides only a framework for the limitation of GHG's, and specific agreements for limiting reductions have yet to be negotiated. ${ }^{4}$

This Note proposes that the international community has failed to negotiate a specific agreement limiting GHG emissions because some nations have more

1. Rio Conference on Environment and Development, 22 ENVTL. POL'Y \& L., 204, 211 (1992) [hereinafter Rio Conference]; see Daniel Bodansky, The United Nations Framework Convention on Climate Change: A Commentary, 18 YALE J. INT'L L. (forthcoming summer 1993); Jessica T. Mathews, Introduction and Overview, in Greenhouse Warming: Negotiating a Global Regime 1 (World Resources Institute, 1991).

2. Bodansky, supra note 1; Rio Conference, supra note 1, at 207.

3. Rio Conference, supra note 1 , at 207.

4. Bodansky, supra note 1; Richard B. Stewart, Environmental Regulation and International Competitiveness, 102 YALE L.J. 2039, 2103 (1993). 
to lose than to gain from an international abatement regime, though the benefit to the world from their participation in such a regime may exceed the costs. Arguing from this premise, the Note advocates an efficiency-maximizing international tradeable emissions permit (ITEP) system that would distribute the costs and benefits of GHG abatement in order to motivate every nation to participate in an abatement agreement.

Part I surveys the scientific and economic analyses of global warming's impact on the international community in order to establish that GHG abatement action is warranted. Economists and lawmakers disagree among themselves because of uncertain scientific data and differing assumptions built into the economic models. However, GHG emissions require an international policy response both because global warming could cause irreversible and catastrophic harm to humans and other species and because an international agreement could lower total abatement costs by increasing the marginal efficiency of abatement investment.

Part II uses game theory to argue that GHG emissions reduction presents a unique problem for international negotiation. Certain nations, including the U.S. and less developed countries (LDC's), may suffer a loss from cooperating in a GHG abatement regime, although the benefits to the world of their cooperation may exceed their costs. This problem is neither a Prisoner's Dilemma (in which the benefits of total cooperation outweigh the benefits of total noncooperation for each player) nor a Deadlock (in which the benefits of total noncooperation outweigh the benefits of total cooperation for each player), but what this Note dubs a "Cooperator's Loss" (in which the total benefits of cooperation outweigh the total benefits of noncooperation, but for one of the two players, total noncooperation nevertheless remains a more attractive alternative than total cooperation).

Part III proposes that an international tradeable emissions permit (ITEP) system could allow transfers that would resolve the Cooperator's Loss, benefiting both developing and developed nations and maximizing the efficiency of international GHG emissions reduction. Industries in developed nations such as the U.S. could then purchase or lease permits at competitive international market rates or receive permits in exchange for relatively low-cost technology transfer. Developing nations would benefit from an infusion of technology and revenue from the sale, lease, or exchange of such permits. Finally, an analysis of the steepness of the marginal cost and marginal benefit curves in the GHG abatement context demonstrates that an ITEP system would be more efficient than a tax system in reducing GHG emissions. 


\section{SCIENTIFIC AND ECONOMIC UNCERTAINTY ABOUT THE IMPACT OF INCREASING GHG CONCENTRATIONS}

\section{A. Sources of Uncertainty}

Before considering how disparate regional and national perspectives present barriers to negotiating an agreement on GHG abatement, ${ }^{5}$ this Part proposes that even from a global perspective, fundamental disagreement about appropriate policy action derives first from scientific uncertainty and second from conflicting assumptions that economists build into models that attempt to predict global warming's economic impact.

On the scientific side, estimates of the warming that will take place after a doubling of $\mathrm{CO}_{2}$ equivalent ${ }^{6}$ vary from 1.5 to $5.5^{\circ} \mathrm{C}\left(2.7\right.$ to $\left.9.9^{\circ} \mathrm{F}\right){ }^{7}$ Researchers are also unsure about how other weather patterns, such as precipitation, may change with global warming and about the impact of such climate changes on humans and other forms of life. ${ }^{8}$ Scientific uncertainty accounts for much of the disagreement over appropriate policy responses to global warming. For example, based on the prediction that increases in temperature will be lowest near the already warm equator, and greatest at the cold poles, Wilfred Beckerman argues that the world as a whole might be better off with global warming..$^{9}$ At the other extreme, Senator George Mitchell focuses on predictions that global warming will gravely disrupt the world's climate patterns, causing an "ecological holocaust" in which thermal swelling of the seas floods entire cities, shifting climate zones displace millions of people, "raging hurricanes" kill millions of others, and droughts "drive [entire continents] ... into mass starvation." 10

Compounding the uncertainty inherent in the scientific data, economists rely on diverse economic assumptions in building their predictive global

5. See infra Part II.

6. The $\mathrm{CO}_{2}$ equivalent of a GHG is the amount of carbon dioxide that would lead to the same level of climate warming as given amounts of other GHG's. William D. Nordhaus, The Cost of Slowing Climate Change: A Survey, 12 ENERGY J. 37, 38 (1991).

7. JoHn FIROR, THE ChANGING ATMOSPHERE 57 (1990); see CoMmitTEe ON SCIENCE, ENGINEERING AND PUBLIC POLICY, POLICY IMPLICATIONS OF GREENHOUSE WARMING 18 (1991) [hereinafter POLICY IMPLICATIONS] (suggesting that the possible range is 1.9 to $5.2^{\circ} \mathrm{C}\left(3.4\right.$ to $\left.9.4^{\circ} \mathrm{F}\right)$ ); OFFICE OF POLICY, PlanNing and EVAluation, U.S. ENVIRONMENTAL PROTECTION AGENCY, POLICY OPTIONS For STABILIZING Global Climate, DRAFT REPORT To CONGRESS, EXECUTIVE SuMMARY 4 (1989) (noting that a warming of $5.5^{\circ} \mathrm{C}$ as a result of doubling of $\mathrm{CO}_{2}$ concentrations may be at least as likely as a warming of $1.5^{\circ} \mathrm{C}$ ).

8. Policy Implications, supra note 7, at 2; see William R. Cline, The ECONOMics of Global Warming 30-31 (1992) (citing Intergovernmental Panel on Climate Change, IPCC First ASSESSMENT REPORT, VOLUME I: OVERVIEW AND SUMMARIES 5-9 (Aug. 1990) (listing potential secondary climate effects, such as droughts, storms and flooding, but suggesting extent and cost of such effects are uncertain)).

9. Wilfred Beckerman, Global Warming: A Sceptical Economic Assessment, in ECONOMIC POLICY TOWARD THE ENVIRONMENT 52, 57 (Dieter Helm ed., 1991).

10. SENATOR GEORGE J. MTTCHELl, World ON Fire 21, 70 (1991). 
warming models. Economists William Nordhaus and William Cline, the only two economists to study both the potential costs and the potential benefits of a GHG abatement regime, ${ }^{11}$ have reached dramatically different conclusions about the efficient level of GHG abatement action because of their differing assumptions regarding the appropriate discount rate to apply to future harms from global warming, ${ }^{12}$ the impact of risk aversion on cost-benefit calculations, ${ }^{13}$ and differing perspectives on harms that may not accrue until the distant future. ${ }^{14}$ While Nordhaus advocates an $11 \%$ reduction in GHG emissions from baseline, ${ }^{15}$ Cline advocates a $25 \%$ reduction from baseline by $2000,{ }^{16} 71 \%$ reduction by $2050,82 \%$ reduction by 2100 , and $90 \%$ reduction by $2200 .{ }^{17}$

\section{B. Accounting for Uncertainty in Designing Policy}

Given the level of uncertainty involved in predicting the impact of global warming, some policymakers would delay significant measures until scientific knowledge is refined, while others have urged that the potential irreversible effects of global warming warrant immediate, aggressive action. This Section

11. See Beckerman, supra note 9, at 62; Richard D. Morgenstem, Towards a Comprehensive Approach to Global Climate Change Mitigation, AM. ECON. REV., May 1991, at 140, 140 (identifying Nordhaus as the only economist to write about both damage and cost functions associated with climate change). Since Morgenstern wrote his article, William Cline has become the second economist to write about both benefit and costs functions. See Cline, supra note 8 , at 8 . Because Nordhaus and Cline are the only two economists to have written about both cost and benefit functions to date, this Note will focus on their contrasting economic analyses.

12. Cline argues that the discount rate applied to calculations of future benefits received from current expenditures should be $2 \%$, in contrast to the $4 \%$ discount rate used by Nordhaus. CLINE, supra note 8 , at 268, 311; William D. Nordhaus, To Slow or Not To Slow: The Economics of the Greenhouse Effect, 101 ECON. J. 920, 926 (1991). Nordhaus uses the 4\% discount figure because "[i]n advanced countries today, the real rate of return on capital is estimated to be between 4 and $10 \%$ per year." Id. He also provides estimates of benefits using a lower discount rate (3\%) and a higher discount rate $(7 \%)$, but refers to the $4 \%$ figure as his "middle discount rate," $i d$. at 934 , and it is the calculations from the $4 \%$ rate that he cites in his final conclusions. See id. at 927 tbl. 3, 936. Cline attaches great weight to the "social rate of time preference" (the discount rate for consumption), which tends to be lower than the rate of return on investment, CLINE, supra note 8, at 236, in calculating his discount rate. Id. at 237-38, 267-68. This method of calculating the discount rate was developed by four economists in the 1960's and 1970's and has been used increasingly by other economists in recent years. $I d$. at 243-44.

13. See CliNe, supra note 8 , at 300 (stating that because of risk aversion, the weight applied to the most severe global warming scenario should be three times the weight applied to the least severe global warming scenario); id. at 309 (concluding that, with risk aversion, there should be much more extensive abatement action than the Nordhaus analysis suggests).

14. Id. at 4,307 . "The estimates here consider much greater warming for the very long term and associated nonlinear damage, whereas the Nordhaus analysis focuses on carbon-dioxide-equivalent doubling." Id. at 311 .

15. Nordhaus, supra note 12 , at $933-34$. Note that an $11 \%$ reduction from the baseline level of emissions would still mean that emissions would increase in the future, but that they would be $11 \%$ lower than if no GHG abatement policy were implemented. Id. at 933. According to Nordhaus' calculations, an $11 \%$ reduction from baseline can be made at very low cost $-\$ 2.9$ billion per year, with a net benefit of $\$ 3.6$ billion. Id. at $934 \&$ tbl. 7 .

16. See CLINE, supra note 8 , at 290 tbl 7.2, 369 (advocating $20 \%$ reduction from 1990 levels by the year 2000 , which is the same as $25 \%$ reduction from year 2000 baseline levels).

17. Id. at 309 . 
argues that a market-based international tradeable emissions permit system would not only reduce the potential for catastrophic and irreversible damage from global warming, but would also reduce the total costs, and thereby increase the net benefits, of GHG abatement. The potential for lower abatement costs reinforces the case for earlier and stronger measures.

From an economic policy perspective, the argument against awaiting greater certainty is that "later" may be too late to take effective action. "The lag time between emission of the gases and their full impact is on the order of decades to centuries."18 Thus the effects of global warming may be almost "irreversible," a term which has important implications for economic and policy analysis. Economists Kip Viscusi and Richard Zeckhauser conclude that "states that are not unattractive in themselves should perhaps be avoided even at considerable cost because they increase the likelihood of future transit to undesirable states." 19

If there is uncertainty, however, about whether the effects are irreversible, then we may learn something valuable during the gradual transition toward the potentially irreversible state..$^{20}$ By cautiously moving toward a global warming state, society may learn more about its potential effects. More informed (and hence efficient) action can follow. Nonetheless, if policymakers are risk averse, the potential for irreversible harm from global warming may outweigh the informational gains of moving toward the global wrarming state. ${ }^{21}$ Even if the alternative methods of acquiring information appear "more expensive," policymakers may prefer them on the theory that they are "buying insurance" against the possibly irreversible and catastrophic effects of global warming. ${ }^{22}$

Cline weighs the value of future learning against the exponentially increasing nature of the greenhouse warming damage function and the potential irreversibility of the accumulation of GHG's. He concludes that there should be a ten-year "phase-in" period of modest cost measures which also provide protection against long-term irreversible harm. ${ }^{23}$ Because Cline argues that ultimately there should be an extremely aggressive GHG abatement effort, ${ }^{24}$ such a phase-in period should arguably include negotiation of an international agreement that would allow the world to take advantage of marginal

18. OfFice of Technology Assessment, U.S. Congress, Changing by Degrees: Steps to REDuCE GREenHouse GASES 3 (1991) [hereinafter CHANGING BY DEGREES].

19. W. Kip Viscusi \& Richard Zeckhauser, Environmental Policy Choice Under Uncertainty, J. ENVTL. ECON. \& MGMT., Oct. 1976, at 97, 105.

20. Id. at 108.

21. See Cline, supra note 8 , at 311.

22. See $i d$. at 303-05; JOSHUA M. EPSTEIN \& RAJ GuPTA, CONTROLling THE GREENHOUSE EFFECT: Five Global Regimes CoMPAREd 7-8 (Brookings Occasional Papers, 1990).

23. CLINE, supra note 8, at 310-11. "This initial modest level of costs helps resolve the tension between the need to begin a relatively aggressive program of action sooner rather than later, on the one hand, and the high return to further scientific verification, on the other." Id. at 311.

24. See supra note 17 and accompanying text. 
efficiencies of action on a global scale and thereby minimize the costs of the aggressive abatement program advocated by Cline. ${ }^{25}$

Nordhaus, in contrast, views the costs of delaying significant action for ten years as minimal. ${ }^{26}$ Nevertheless, he suggests that because GHG emissions have been an externality which industries have not had to consider when making production decisions, even extremely low-cost measures that could have reduced GHG emissions have not yet been implemented. Nordhaus therefore argues that restrained measures could be adopted in the short term at very low cost. ${ }^{27}$ Because "[ $\left[\right.$ t]he first units of reduction of $\mathrm{CO}_{2}$ and other greenhouse gases are virtually free, ${ }^{, 28}$ such restrained action arguably does not require international agreement; nations should be motivated to take such action on their own purely to promote their own economic welfare. ${ }^{29}$ Under the Nordhaus analysis, the costs of more aggressive action exceed the benefits, ${ }^{30}$ hence, the need for an international agreement is less pressing than it is under the Cline analysis.

From a global efficiency perspective, however, the Nordhaus analysis contains a major flaw. As Nordhaus acknowledges, "the empirical estimates [of costs of abatement] apply primarily to data for the United States, while we have extended these to apply to the global economy."31 Yet there is strong evidence that U.S. cost data cannot be applied to the global economy because the marginal costs of abatement vary considerably among nations. ${ }^{32}$ If the world can negotiate an agreement that would allow nations to take advantage of the greater marginal efficiency of abatement action over a wider range of investment levels in developing nations, as will be argued below, ${ }^{33}$ then all nations would enjoy lower costs and greater net benefits from abatement action than they would realize if they merely implemented individual domestic abatement measures. Hence, if GHG abatement is undertaken on a global scale,

25. See infra text accompanying notes 32-33.

26. William D. Nordhaus, Rolling the "DICE": AN Optimal Transition Path for CONTROLLING GREENHOUSE GASES 18-19 \& tbl. 1 (Cowles Foundation for Research in Economics at Yale University Discussion Paper No. 1019, 1992).

27. Nordhaus, supra note 6 , at 41 ; Nordhaus, supra note 12 , at $923,936$.

28. Nordhaus, supra note 6 , at 41 .

29. This reasoning may help explain why numerous OECD nations have unilaterally adopted GHG emissions abatement targets. See infra note 83 and accompanying text. Notably, however, the U.S. did not join this movement among developed countries, although there are signs that it may do so under the Clinton Administration, see infra note 87 and accompanying text, especially given Vice President Gore's strong commitment to immediate action on GHG abatement. See Policy Implications of Greenhouse Warming: Hearings Before the Senate Comm. on Commerce, Science, and Transportation, 102d Cong., 1st Sess. 2-3 (1991).

30. Nordhaus, supra note 12 , at $934 \&$ tbl. 7 . The $20 \%$ level of GHG reduction from baseline would cost $\$ 16.3$ billion per year, more than five times as much as Nordhaus' efficient $11 \%$ level, and would lead to a net loss of $\$ 4.4$ billion per year. $I d$.

31. Nordhaus, supra note 6 , at 63 ; see also Nordhaus, supra note 12 , at 933,936 (acknowledging that a complete assessment of the impact of global warming should include regions outside the U.S. but concluding that lack of data makes conclusions about other areas impossible).

32. See infra note 59 and accompanying text.

33. See infra text accompanying notes 59-60. 
the cost of abatement could be considerably less than Nordhaus predicts. This possibility casts serious doubt on Nordhaus' conclusion that the benefits of aggressive abatement action do not outweigh the costs. When the lower costs from more efficient international action are considered, the marginal cost of abatement curve shifts down (right), and a higher level of abatement activity becomes efficient. Because Cline's analysis suggests that an aggressive international GHG abatement regime would be efficient, and one could infer from Nordhaus' analysis that moderate action may be efficient, this Note will proceed on the assumption that the benefits of moderate to aggressive international efforts to limit GHG emissions would exceed the costs.

\section{Obstacles to Negotiating a Solutton to the Greenhouse WARMING PROBLEM}

\section{A. The "Cooperator's Loss" Model}

Greenhouse gas emissions disperse throughout the global atmosphere whatever the source of the emissions, and the benefits of any abatement activities are similarly shared by the world as a whole. ${ }^{34}$ Hence, nations have strong incentives to "free ride" on the actions of other nations. ${ }^{35}$ Numerous analysts have therefore argued for an international solution. ${ }^{36}$

Because of the "free rider" problem, Cline has pointed out that the Prisoner's Dilemma serves as a useful model for the difficulties involved in negotiating an international GHG abatement agreement. ${ }^{37}$ In the classic Prisoner's Dilemma, because each party perceives noncooperation as maximizing its individual welfare, there is a perverse incentive for two parties not to cooperate even though cooperation would maximize total benefit. ${ }^{38}$ In

34. Gary E. Marchant, Global Warming: Freezing Carbon Dioxide Emissions: An Offset Policy for Slowing Global Warming, 22 ENVTL. L. 623, 636 (1992); James K. Sebenius, Crafting a Winning Coalition: Negotiating a Regime to Control Global Warming, in GREENHOUSE WARMinG: NEGOTIATING A GLOBAL REGIME, supra note 1, at 69, 73; see also POLICY IMPLICATIONS, supra note 7, at 3-4.

35. CLINE, supra note 8, at 327-28; Sebenius, supra note 34 , at 73.

36. POLICY IMPLICATIONS, supra note 7, at 2; T.C. Schelling, Economic Responses to Global Warming: Prospects for Cooperative Approaches, in GLOBAL WARMING: ECONOMIC POLICY RESPONSES 197, 198 (Rudiger Dornbusch \& James M. Poterba eds., 1991); see also MiCHAEL GruBB, THE GREENHOUSE EFFECT: NEGOTIATING TARGETS 2 (1989).

37. CLINE, supra note 8 , at 325-27.

38. ROBERT AXELROD, THE EVOLUTION OF COOPERATION 7-9 (1984). Thus, in one example of the game, both players receive 3 points if there is mutual cooperation, for a total of 6 , and 1 point if there is mutual noncooperation, for a total of 2 . If one player cooperates while the other does not, the cooperating player (the "sucker") receives no points, while the noncooperating player (the "defector") receives 5 points, for a total of 5 . The matrix below illustrates this classic Prisoner's Dilemma: 
the global warming context, each nation may perceive that the individual costs of its abatement action exceed the benefits it will realize, since the benefits of abatement are dispersed globally. Hence, absent an enforceable international agreement, individual nations may lack incentives for unilateral action. ${ }^{39}$

But there is an additional complication which differentiates negotiation on global warming from the Prisoner's Dilemma. Certain nations may have more to lose by cooperating in an international GHG abatement scheme than they have to lose from unabated global warming itself, even though the value of their cooperation to the world might exceed their internalized costs of cooperating. ${ }^{40}$ Using the above notation, ${ }^{41}$ this group of nations would face a preference ordering of $\mathrm{DC}>\mathrm{DD}>\mathrm{CC}>\mathrm{CD}$. When both players have this preference ordering, the game is called "Deadlock," which is different from the Prisoner's Dilemma (DC > CC > DD > CD) because mutual cooperation is not preferred to mutual defection. ${ }^{42}$ Yet in the scenario described here one group of nations prefers mutual cooperation to mutual defection (CC to DD) and one group prefers the opposite (DD to $\mathrm{CC}$ ). This situation is neither completely a

FIGURE 1. The Prisoner's Dilemma

\begin{tabular}{cc|c|c|c|c|} 
& \multicolumn{4}{c}{ Player B } \\
& & \multicolumn{1}{c}{ Cooperate } & \multicolumn{2}{c}{ Defect } \\
\hline \multirow{2}{*}{ Player A } & B & A & B \\
\hline 3 & 3 & 0 & 5 \\
\hline 5 & 0 & 1 & 1 \\
\hline
\end{tabular}

Using the notation that has been developed for game theory, with $\mathrm{C}$ representing "cooperate" and D representing "defect," in a Prisoner's Dilemma each player has a preference ordering of $\mathrm{DC}>\mathrm{CC}>\mathrm{DD}>\mathrm{CD}$ from her individual perspective, with the first letter in each pair representing what the player herself does, and the second letter representing what the player's opponent does. See Kenneth A. Oye, Explaining Cooperation Under Anarchy: Hypotheses and Strategies, in COOPERATION UNDER ANARCHY 1, 7 (Kenneth Oye ed., 1986). Thus, each player has an incentive to defect, no matter what the other player does, since $\mathrm{DC}>\mathrm{CC}$, and $\mathrm{DD}>\mathrm{CD}$. However, from a global perspective (the perspective of a strategist standing outside the game whose goal is to maximize the total number of points), the preference ordering would be $\mathrm{CC}>(\mathrm{DC}=\mathrm{CD})>\mathrm{DD}$, where " $=$ " indicates that a strategist would be indifferent between two outcomes. The "equilibrium outcome" in a Prisoner's Dilemma (DD) is thus the least preferable position from this perspective. The equilibrium outcome is defined as "one from which neither player can shift without impairing his payoff, assuming that the other player does not shift." ANATOL RAPOPORT ET AL., THE 2 X 2 GAME 18 (1976). It is therefore the outcome that will prevail absent communication and cooperation between the parties to achieve a different outcome.

39. Even though numerous European Community and OECD nations have made unilateral commitments to limit GHG emissions, infra note 83 and accompanying text, some members of the European Community have argued that they should not move forward with plans for a carbon tax, since unabated GHG emissions in the U.S. would simply undercut their own abatement efforts. Lakshman Guruswamy, Integrated Environmental Control: The Expanding Matrix, 22 ENVTL. L. 77, 79 (1992).

40. The ensuing discussion assumes the organization of nations into two groups, each acting as a single "player"-one group believing that its costs in an international GHG abatement regime would exceed its share of the benefits, and the other believing that its share of the benefits would exceed its costs.

41. See supra note 38 .

42. Robert Axelrod \& Robert O. Keohane, Achieving Cooperation Under Anarchy: Strategies and Institutions, in COOPERATION UNDER ANARCHY, supra note 38, at 226, 230. 
Prisoner's Dilemma nor a Deadlock, but an asymmetric ${ }^{43}$ combination of the two, as one player has a Prisoner's Dilemma preference ordering, and the other player has a Deadlock preference ordering. I will refer to this asymmetric game as the Cooperator's Loss: one party must suffer a loss in order to reach the cooperative solution that maximizes total welfare. ${ }^{44}$

In the global warming context, when the costs of abatement to a given nation are greater than that nation's share of the total gains from abatement, that nation will have no incentive to strive for the cooperative solution, and there is a Cooperator's Loss. Therefore, to induce cooperation in a Cooperator's Loss situation, part of the overall gain must be transferred from one "player" to the other.

\section{B. Examples of Potential Cooperator's Losses}

It is currently impossible to know which if any nations would suffer a Cooperator's Loss, given uncertainties about global warming's extent and the distribution of its effects among the regions of the world. ${ }^{45}$ Nonetheless, when accounting for current expectations about the costs and benefits of GHG abatement, various nations throughout the world may expect that they would face a Cooperator's Loss-i.e., that they would be worse off as individual nations under an abatement regime than they would be in a "business as usual" scenario. Two classes of nations may reasonably believe that they face the "loser's" preference ordering ${ }^{46}$ in a Cooperator's Loss: first, Third World

43. Glenn H. Snyder \& Paul Diesing, Conflict among Nations: Bargaining, Decision MAKING, AND SYSTEM STRUCTURE IN INTERNATIONAL CRISES 46 (1977).

44. Using a game theory matrix, an example of a Cooperator's Loss is illustrated below:

FIGURE 2. The Cooperator's Loss

\begin{tabular}{cc|c|c|c|c||} 
& \multicolumn{4}{c}{ Player B } \\
& & \multicolumn{2}{c}{ Cooperate } & \multicolumn{2}{c|}{ Defect } \\
\hline \hline \multirow{2}{*}{ Player A } & Cooperate & B & A & B \\
\hline \hline 4 & 2 & 0 & 5 \\
\hline 5 & Defect & 0 & 1 & 3 \\
\hline
\end{tabular}

Player A has a preference ordering of $\mathrm{DC}>\mathrm{CC}>\mathrm{DD}>\mathrm{CD}$ as in a Prisoner's Dilemma, while player $\mathrm{B}$ has a preference ordering of $\mathrm{DC}>\mathrm{DD}>\mathrm{CC}>\mathrm{CD}$ as in Deadlock. The preference ordering from a global utility maximizing perspective is $C C>(D C=C D)>D D$ as in a Prisoner's Dilemma.

45. Intergovernmental Panel on Climate Change, Climate Change: The IPCC Scientific ASSESSMENT xxiv, 157-58 \& fig. 5.4 (J.T. Houghton et al. eds., Cambridge University Press 1990) [hereinafter IPCC SCIENTIFIC ASSESSMENT]; Sebenius, supra note 34, at 73-74; William K. Stevens, Estimates of Warming Gain More Precision and Warn of Disaster, N.Y. TIMES, Dec. 15, 1992, at Cl; see also EPSTEIN \& GUPTA, supra note 22, at 6 (pointing out that regional impacts are not reflected in global surface warming estimates).

46. In the ensuing discussion, the "loser's" preference ordering corresponds to the Deadlock side of the Cooperator's Loss (DC > DD > CC > CD); the "winner's" preference ordering corresponds to the 
nations whose gains from rapid industrialization may outweigh the shared welfare loss from unabated global warming; ${ }^{47}$ second, industrialized nations, in particular the U.S., whose dependence upon GHG-emitting fuels and industries is so severe that the costs to them of significantly reducing GHG emissions would outweigh their share of the global benefits of such reduction. ${ }^{48}$ The Cooperator's Loss model may thus help explain why both LDC's and the U.S. have been reluctant to enter into a GHG abatement agreement committing these nations to particular target reductions. ${ }^{49}$

\section{Less Developed Countries Facing a Cooperator's Loss}

The proposition that the Third World faces a Cooperator's Loss is controversial. Because LDC's economies depend upon agriculture more than the economies of industrialized nations, some have argued that Third World nations face a more significant threat from global warming than do developed nations. $^{50}$ This argument implies that LDC's might have more to gain than to lose from a GHG abatement regime, and therefore do not face a Cooperator's Loss, since abatement would avert the climate change that might otherwise disrupt LDC's agricultural system.

In proposing that LDC's may face a Cooperator's Loss, this Note challenges the above argument on several grounds. First, most of the current climate change models predict that regions closer to the equator will face far less extreme temperature changes than areas closer to the poles. ${ }^{51}$ Second,

Prisoner's Dilemma side of the Cooperator's Loss (DC $>C C>D D>C D)$.

47. See infra notes 51-52 and accompanying text.

48. See Guruswamy, supra note 39, at 77; Treaty Ratification Urged by Gore, Reilly, Industry, Environmentalists, 1992 Daily Rep. for Executives (BNA) 183 (Sept. 21, 1992); cf. Money, U.S. Position Remain Barriers for Accord on Climate Change Issues, 14 Int'l Envtl. Rep. (BNA) 502 (Sept. 27, 1991) (pointing out that because U.S. is endowed with large coal reserves, it is reluctant to agree to fossil fuel reduction targets).

A third group may also face the loser's preference ordering: nations in extremely cold regions that might actually benefit from the effects of global warming. See CLINE, supra note 8, at 332 (suggesting that agricultural effects of global warming would benefit a few high latitude nations, including Denmark, Finland, and Iceland). Finally, current generations may face a Cooperator's Loss with respect to future generations which might reap the larger portion of the benefits from GHG abatement action taken in the short term. See Sebenius, supra note 34, at 73 (arguing that individual nations and industries have less incentive to reduce emissions than they would have if the benefits of abatement action were felt immediately). Discussion of a potential Cooperator's Loss in these two situations is beyond the scope of this Note. For an argument that nations have an obligation to consider the interests of future generations when designing environmental policy, see Edith Brown Weiss, Our Rights and Obligations to Future Generations for the Environment, 84 AM. J. INT'L. L. 198 (1990).

49. See infra notes $79-84$ and accompanying text; GRUBB, supra note 36 , at 24 (pointing out developing countries' resistance to constraints on future emissions of GHG's); Ria Conference, supra note 1, at 207 (stating that the Convention on Climate Change was watered down at U.S. insistence); Christopher D. Stone, Beyond Rio: "Insuring" Against Global Warming, 86 AM. J. INT'L L. 445, 453 (1992).

50. Schelling, supra note 36, at 202-03; Greenhouse Economists Still Disagree, But Some Differences Begin to Narrow, GLOBAL ENVTL. CHANGE REP., May 17, 1992, available in LEXIS, Nexis Library, ZEV1 File.

51. Beckerman, supra note 9, at 57; William R. Cline, Comment on Economic Responses to Global Warming: Prospects for Cooperative Approaches, in GLOBAL WARMING: ECONOMIC POLICY RESPONSES, 
industrialization in LDC's, with its concomitant economic benefits, is closely tied to increasing GHG emissions. ${ }^{52}$ Hence, if LDC's are required to implement industry-suppressing GHG abatement strategies, they would forgo the economic benefits that would accrue to them from unrestrained industrialization. ${ }^{53}$ Such gains arguably exceed the agricultural losses that LDC's would face under global warming, ${ }^{54}$ especially considering that LDC's are generally clustered in equatorial regions where temperature changes will be less severe..$^{55}$ The World Bank's 1992 Development and the Environment report argues that developing nations would gain more from industrialization than from GHG abatement. ${ }^{56}$ Third, it has been argued that a clean environment is a "luxury" good that developing nations value less than do industrialized nations. ${ }^{57}$ Finally, if Third World nations do industrialize at the expense of GHG abatement, their economies will be that much less dependent upon agriculture, and the effects of global warming upon their economies will be that much less severe. ${ }^{58}$ Developing nations could therefore lose more from GHG abatement activity than they would gain.

Although the Third World may face a Cooperator's Loss, numerous commentators have suggested that from an international perspective the marginal efficiency of GHG abatement in the Third World would probably exceed the efficiency of such investment in the developed world over a wider range of investment levels. ${ }^{59}$ For example, relatively low cost improvements

supra note 36, at 222, 225-26; see also IPCC SCIENTIFIC ASSESSMENT, supra note 45, at 157-58 \& fig. 5.4 (indicating that areas closer to equator may experience less extreme temperature change from global warming).

52. Michael Weisskopf, Global Warming Rift Threatens Treaty: U.N. Talks Close With Industrialized Nations, Third World at Odds, WASH. POST, Feb. 28, 1992, at A3.

53. See Stewart, supra note 4, at 2053; Richard B. Stewart \& Jonathan B. Wiener, The Comprehensive Approach to Global Climate Policy: Issues of Design and Practicality, 9 ARIZ. J. INT'L \& COMP. L. 83, 107 (1992).

54. GRUBB, supra note 36 , at 20.

55. GHG abatement need not involve major sacrifices to industrialization if "green technologies" are implemented, but the green technology option would not be available to LDC's absent cooperation and technology transfer from the developed world. Green technology transfer will be advocated below as part of the strategy for resolving the developing world's Cooperator's Loss while minimizing the global costs of GHG abatement. See infra text accompanying notes 107-109.

56. Sylvia Nasar, Conference in Rio: The Rich vs. the Poor; Cooling the Globe Would be Nice, But Saving Lives Now May Cost Less, N.Y. TIMES, May 31, 1992, § 4, at 6 (citing 1992 World Bank Report).

57. Stewart, supra note 4, at 2052. "Because of their more urgent need for economic development, citizens of developing countries often place a lower value on reducing environmental externalities than citizens of developed countries." Id. at 2099.

58. See Nasar, supra note 56.

59. See, e.g., Cline, supra note 8, at 338-40 (arguing that there is great potential for low cost abatement measures in developing countries because of relatively inefficient energy use as compared to Western Europe and use of energy subsidies); JOSE GOLDEMBERG ET AL., ENERGY FOR A SUSTAINABLE WORLD 86 (1987) (arguing that implementation of modemized, efficient energy technologies in the developing world would be less costly than using conventional, less efficient technologies and increased energies supplies); Morgenstern, supra note 11, at 140; Stewart \& Wiener, supra note 53, at 108; Urgent Use of Realistic Pricing Systems, Economic Reporting Methods Needed in East, Int'l Env't Daily (BNA), Dec. 9, 1991, available in LEXIS, Nexis Library, BNAIED File; cf. PoLICY IMPLICATIONS, supra note 7, at 47 (suggesting that efforts in developing nations could prove to be most efficient strategy for U.S.). 
in environmental technology and design efficiency in developing nations, using technology already available in the industrialized world, could have a much greater impact in reducing GHG emissions than higher cost improvements in developed nations. The relatively low cost of such improvements in developing countries, however, does not imply that the globally efficient solution would come at low cost to developing nations. Rather, the globally efficient GHG abatement program may require greater overall investment in LDC's, in order to take advantage of these marginal efficiencies. Moreover, differences in standards of living and the availability of "green technologies" between the developing and developed worlds may mean that an abatement cost which is low by industrialized nations' standards is nonetheless quite burdensome in developing countries.

Given that roughly three-quarters of the world's population resides in developing nations, ${ }^{60}$ and that efficiency interests require that investment in GHG abatement be concentrated in the developing world, I hypothesize for the sake of illustration below that it will be efficient to require roughly twice as much GHG abatement investment in developing nations as in developed nations. Based on my analysis regarding the greater marginal efficiency of abatement in developing nations over a wider range of investment levels, such investment might achieve an efficient (though not necessarily equitable) distribution of burdens between the developed and the developing worlds. ${ }^{61}$

A compromise between Nordhaus' and Cline's conclusions about the efficient level of abatement action suggests that approximately $\$ 33$ billion $^{62}$ of investment per year worldwide might lead to an efficient level of abatement. ${ }^{63}$ According to the hypothesis in the previous paragraph, the efficient solution might then require about $\$ 10 \mathrm{~B}$ of investment in the developed world and $\$ 23 \mathrm{~B}$ of investment in the developing world (to take advantage of the higher marginal efficiency of investment in the developing world over a wider range of investment levels). Suppose that each nation is responsible for the costs of abatement activity in its own nation. ${ }^{64}$ Applying

60. Changing By Degrees, supra note 18, at 33, fig. 1-11 (1991).

61. Efficiency should not be confused with equity. So far, the discussion has addressed only the issue of minimizing the total costs of GHG abatement. Minimizing total costs, however, is an important first step toward an equitable solution, as it reduces the international burden in achieving GHG abatement, and thus, all other things being equal, increases a nation's willingness to accept its share of the reduced burden. The resolution to the Cooperator's Loss problem, below, will involve a transfer of resources that addresses the equity issue.

62. Hereinafter, billion is abbreviated "B."

63. A $\$ 33 \mathrm{~B}$ per year investment would lead to a $25-30 \%$ reduction from baseline, according to Nordhaus' cost data. Nordhaus, supra note 12, at 934 . This figure is between the $11 \%$ reduction from baseline Nordhaus advocates, $i d$. at 934 , and the more than $70 \%$ reduction from baseline Cline advocates in the long term, see CLINE, supra note 8 , at 309 . In the short term, Cline advocates roughly $25 \%$ reduction from baseline by the year 2000. See id. at $290 \mathrm{tbl}$. 7.2, 369 (advocating $20 \%$ reduction from 1990 levels by the year 2000 , which is the same as $25 \%$ reduction from year 2000 baseline levels).

64. This assumption follows from the idea that a sovereign nation should be responsible for the costs of poliution control within its own borders. In resolving the Cooperator's Loss below, however, this assumption will be re-examined. 
Cline's conclusion that the final weighted benefit-cost ratio is $1.26,{ }^{65}$ the total benefit from investment when there is global cooperation is $\$ 33 \mathrm{~B} \times 1.26=$ $\$ 42 \mathrm{~B}$, while the net benefit is $\$ 42 \mathrm{~B}-\$ 33 \mathrm{~B}=\$ 9 \mathrm{~B}^{66}$

Assume that the developed and the developing worlds share the benefits of GHG abatement fifty-fifty, each receiving $\$ 21 \mathrm{~B}^{67}$ The net return to the developed world, which invests $\$ 10 \mathrm{~B}$, is $21-10=\$ 11 \mathrm{~B}$. The net loss to the developing world, which invests $\$ 23 \mathrm{~B}$, is $21-23=\$-2 \mathrm{~B}$. The northwest ("total cooperation") quadrant of the matrix below reflects these returns. ${ }^{68}$ The northeast and southwest quadrants reflect the situation when only one side or the other cooperates, but not both. ${ }^{69}$ The resulting choice matrix is illustrated below:

65. CLINE, supra note 8 , at 300 .

66. As numerous economists have pointed out, many of the benefits of global warming are difficult to quantify in dollar terms, such as preservation of coastal wetlands and biological diversity. Morgenstern has criticized some economists, including Nordhaus, for failing to account for such benefits. Morgenstern, supra note 11, at 140,141-42. The model proposed in this Note does not assume such benefits should be ignored, but rather assumes they can somehow be quantified in dollar terms.

67. This is a simplifying assumption, but not an arbitrary one: as noted above, the developing world has nearly three-quarters of the world's population, but temperature change will be less severe closer to the equator. Moreover, if a clean environment is a "luxury good" that is valued less by developing nations, see supra note 57 and accompanying text, then the benefits of abatement action will be valued less in the Third World than in the First World. Hence, the developing world may have less to gain per capita from GHG abatement than the developed world.

68. For the sake of clarity, dollar signs and billions are omitted from the matrixes.

69 . In the northeast quadrant, the First World invests its $\$ 10 \mathrm{~B}$ in abatement activity, with a return to the world as a whole of $\$ 12 \mathrm{~B}$; however, the LDC's do not make any investment. The return to the First World is $\$ 6 \mathrm{~B}$ (its half of the benefit) minus $\$ 10 \mathrm{~B}$ (its investment) for a net total of $-\$ 4 \mathrm{~B}$ (a $\$ 4 \mathrm{~B}$ loss); the return to the Third World is simply $\$ 6 \mathrm{~B}$ (its half of the benefit) since it makes no investment. In the southwest quadrant, the Third World invests its $\$ 23 \mathrm{~B}$ in abatement activity, with a return to the world as a whole of $\$ 30 \mathrm{~B}$. The return to the First World is simply $\$ 15 \mathrm{~B}$ (its half of the benefit), while the return to the Third World is $\$ 15 \mathrm{~B}$ minus $\$ 23 \mathrm{~B}$ (its investment), for a net $\$ 8$ B loss. The percentage return from Third World investment alone (roughly $30 \%$ of its investment) is greater than the percentage return from First World investment alone ( $20 \%$ of its investment) because the marginal efficiency of investment in the developing world is greater over a wider range of investment levels. See supra notes 59 \& 66 and accompanying text. In the southeast ("no cooperation") scenario, there is simply no investment and no return; this is the "business as usual" scenario. It should be noted that if the First and Third Worlds cooperate to attain the overall efficient solution, the marginal efficiency of investment in each part of the world will be equal when the world reaches its equilibrium level of investment. 
FIGURE 3. The LDC Cooperator's Loss

\begin{tabular}{|c|c|c|c|c|c|}
\hline & \multicolumn{4}{|c|}{ Third World } \\
\hline & & \multicolumn{2}{|c|}{ Cooperate } & \multicolumn{2}{|c|}{ Defect } \\
\hline & & $1 \mathrm{st}$ & 3 rd & 1st & $3 \mathrm{rd}$ \\
\hline \multirow{2}{*}{$\begin{array}{l}\text { First } \\
\text { World }\end{array}$} & Cooperate & 11 & -2 & -4 & 6 \\
\hline & Defect & 15 & -8 & 0 & 0 \\
\hline
\end{tabular}

The First World's preference ordering is $\mathrm{DC}>\mathrm{CC}>\mathrm{DD}>\mathrm{CD}$ (the Prisoner's Dilemma side of the Cooperator's Loss). The Third World's preference ordering is $\mathrm{DC}>\mathrm{DD}>\mathrm{CC}>\mathrm{CD}$ (the Deadlock side of the Cooperator's Loss). The globally efficient preference ordering is $\mathrm{CC}>\mathrm{DC}>\mathrm{CD}>\mathrm{DD}$. The key point is that the Third World's contribution is efficient from a global perspective, but the Third World would nonetheless prefer the completely noncooperative solution ${ }^{70}$ over the cooperative solution. ${ }^{71}$

In this example, in order to make the Third World prefer the total cooperative solution (international abatement) over the total noncooperative solution (no abatement), the First World would have to transfer back ${ }^{72}$ to the developing world at least $\$ 2 \mathrm{~B}$ gained from the cooperation. ${ }^{73}$ The choice matrix would then appear as follows: ${ }^{74}$

70. Southeast quadrant, with total net returns of 0 , and net returns to the Third World of 0 .

71. Northwest quadrant, with total net returns of $\$ 9 \mathrm{~B}$, but net loss to the Third World of $\$ 2 \mathrm{~B}$.

72. Such transfers are appropriately viewed as a return of what is owed, rather than a "gift," to cooperating developing nations, since their cooperation creates a benefit which might otherwise be reaped exclusively by developed nations.

73. In order to make the developing world actually prefer the efficient solution, the developed world would have to transfer slightly more than $\$ 2 \mathrm{~B}$, or $\$ 2 \mathrm{~B}+\epsilon$, where $\epsilon=\mathrm{a}$ minimal amount. To simplify the notation, this Note omits the $\epsilon$ 's and assumes throughout that a "player" will always cooperate when it is indifferent between two alternatives.

74. Part III, infra, will discuss a possible regime for making such a transfer. Note that game theory requires a transfer of only $\$ 2 \mathrm{~B}$. Arguably, equity would require the developed world to transfer even more of its gain to the Third World, as a $\$ 2 \mathrm{~B}$ transfer would still leave it with $\$ 9 \mathrm{~B}$ gain, and the Third World at the break even point. A more equitable solution would be a transfer of $\$ 6.5 \mathrm{~B}$, leaving each "side" with a gain of $\$ 4.5 \mathrm{~B}$ over the noncooperative solution. Also note that from a theoretical perspective, a threatened sanction against the developing world of $\$ 2 \mathrm{~B}$ in the noncooperative scenario would be equally effective for the purposes of inducing cooperation. As argued more fully below, infra note 94, sanctions would be unfeasible when a large number of countries do not cooperate because the threat of sanctions would not be credible. Aside from unfeasibility, however, the sanctions would be gravely inequitable as the First World would reap the benefits of the Third World's abatement expenditures. 
FIGURE 4. The LDC Cooperator's Loss After Incentive Transfer

\begin{tabular}{|c|c|c|c|c|c|}
\hline & \multicolumn{4}{|c|}{ Third World } \\
\hline & & \multicolumn{2}{|c|}{ Cooperate } & \multicolumn{2}{|c|}{ Defect } \\
\hline & & $1 s t$ & $3 \mathrm{rd}$ & $1 \mathrm{st}$ & $3 \mathrm{rd}$ \\
\hline \multirow{2}{*}{$\begin{array}{l}\text { First } \\
\text { World }\end{array}$} & Cooperate & 9 & 0 & -4 & 6 \\
\hline & Defect & 15 & -8 & 0 & 0 \\
\hline
\end{tabular}

Yet even after such a transfer the classic Prisoner's Dilemma situation remains: in the absence of a binding agreement, each side, examining its own options as a profit maximizer, would choose not to cooperate. At this point, the introduction of an international agreement could induce cooperation if it imposes tariff penalties against noncooperators so that the net gain to either side in the cooperative scenario exceeds its net gain in the noncooperative scenario. On the basis of Figure 4, the Third World would have to transfer $\$ 6$ $\mathrm{B}$ to the First World in the northeast quadrant as a tariff penalty for noncooperation, and the First World would have to transfer $\$ 6$ B to the Third World in the southwest quadrant as a similar penalty. ${ }^{75}$

The final result, including the initial transfer to the Third World and subsequent tariff penalties for noncooperation, would be depicted as follows: ${ }^{76}$

FIGURE 5. The Resolution: The LDC Cooperator's Loss After Incentive Transfer and Penalty Tariff

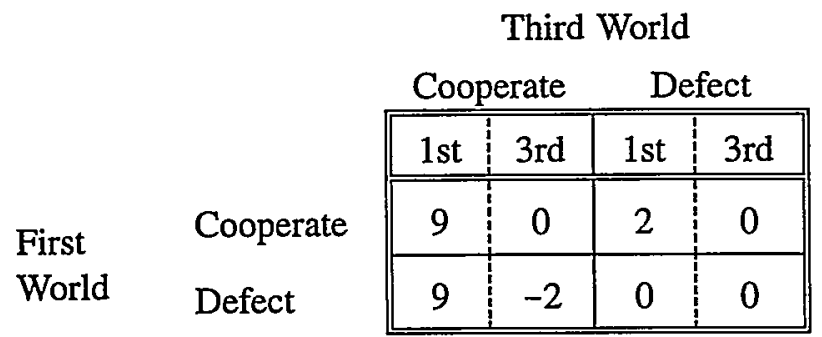

75. It is coincidental that these figures lead to an equivalent penalty tariff for both the developing and developed worlds. An equivalent tariff is not an inherent feature of the Cooperator's Loss or the Prisoner's Dilemma.

76. Since we are dealing with the entire world in this example, the tariff on the noncooperator would have to accrue to the benefit of the cooperator-which is not only a necessary result, but a just one. 
The First World has preferences of $\mathrm{CC}>\mathrm{DC}>\mathrm{CD}>\mathrm{DD}$, and the Third World has preferences of $\mathrm{CC}>(\mathrm{DC}=\mathrm{DD})>\mathrm{CD} .^{77}$ Hence, under the conditions illustrated in Figure 5, the best choice for each block of countries acting as self-interested wealth maximizers is now total cooperation. Note that the tariff penalties in the northeast and southwest quadrants must be credible threats in order to induce cooperation, but in the presence of cooperation, such threats need not be carried out. The form of the threats could be an internationally negotiated import tariff against the products from a noncooperating nation. The Montreal Protocol regulating chlorofluorocarbon (CFC) emissions provides a precedent for such a punitive action. ${ }^{78}$ In contrast, the transfer of $\$ 2 \mathrm{~B}$ from the developed world to the developing world in the northwest quadrant must take place, as the developing world would have no economic incentive to cooperate without it.

\section{The United States: Cooperator's Loss in an Industrialized Country with Severe Dependence on GHG-Emitting Fuels and Technologies}

While the above analysis indicates that a transfer of resources to the Third World may be necessary in order to achieve an efficient abatement regime, the U.S. has been reluctant to make such transfers. Indeed the U.S. has thus far declined to take any active role in worldwide GHG abatement efforts. ${ }^{79}$ It has been argued that an international accord cannot be reached without U.S. participation, if not U.S. leadership. ${ }^{80}$ With $5 \%$ of the world's population and $25 \%$ of the world's GNP, the U.S. accounts for almost $25 \%$ of global GHG emissions, ${ }^{81}$ making it the world's leading contributor ${ }^{82}$ Under the Bush Administration, the U.S. was the only member of the 24-nation Organization for Economic Cooperation and Development and the only industrialized nation worldwide that had not committed to freezing $\mathrm{CO}_{2}$ emissions at 1990 levels by the year 2000. ${ }^{83}$ Especially following the United Nations Conference on the Environment and Development in the summer of $1992,{ }^{84}$ the U.S. was

77. These preferences will result, assuming that players choose cooperation over defection when the payoff between the two is the same. This assumption is not essential to the outcome, as an additional $\in$ could have been transferred in each case. See supra note 73 .

78. Stewart, supra note 4 , at 2101.

79. Schelling, supra note 36 , at 206. U.S. policy on global warming, however, has begun to shift under the Clinton Administration. See infra notes 86-88 and accompanying text.

80. Id.; Developments in the Law-International Environmental Law, 104 HARV. L. REV. 1484, 154750 (1991).

81. GrubB, supra note 36, at 15-16; Thomas F. Berg, Global Warming on Capitol Hill, PUB. UTIL. FoRT., Sept. 1, 1991, at 30.

82. Stone, supra note 49 , at 453.

83. Berg, supra note 81 ; Weisskopf, supra note 52, at A3; see also CHANGING BY DEGREES, supra note 18 , at 7 n.6 (naming a dozen industrialized nations that have pledged to stabilize or reduce $\mathrm{CO}_{2}$ emissions by 2005); CLINE, supra note 8, at 324.

84. See Rio Conference, supra note 1 , at 207. 
gaining a reputation as a spoiler of international agreement on global warming. ${ }^{85}$

President Clinton has recently repudiated Bush Administration policy on GHG abatement, ${ }^{86}$ and during the campaign advocated a domestic marketbased $\mathrm{CO}_{2}$ tradeable emissions permit system similar to the international system proposed in Part III of this Note. ${ }^{87}$ It is worthwhile to consider whether aggressive U.S. action to reduce GHG emissions would conflict with the Clinton Administration's economic recovery goals. ${ }^{88}$ Economists Alan Manne and Richard Richels estimate that freezing emissions at their 1990 rate through 2000 and gradually reducing them to $80 \%$ of this rate by the year 2020 (a more aggressive plan than the one advocated by President Clinton) ${ }^{89}$ would cost the U.S. up to $\$ 3.6$ trillion by $2100 .{ }^{90}$ While the Manne \& Richels study does not estimate the potential benefits of abatement, William Nordhaus has argued that the U.S. economy, like that of other industrial and servicebased economies, is less affected by outside climate because most industrial and service activities take place indoors. ${ }^{91}$ Finally, because the U.S. emits the largest amount of GHG's, ${ }^{92}$ in any GHG abatement regime in which the burden of cleanup costs is distributed on the basis of historical and current emissions, the U.S. will absorb a huge proportion of the world's abatement costs and reap a much smaller percentage of the benefits.

Hence, there is a strong case to be made that the U.S. faces a Cooperator's Loss, a possibility which raises complex questions of international relations and ethics. Should transfers be made to the U.S., one of the world's richest nations, in order to induce its participation in a GHG abatement regime? Alternatively, should the U.S. be willing to make an economic "sacrifice," participating in a GHG abatement regime for the greater good of the world? After winning the campaign on promises of promoting domestic economic concerns, ${ }^{93}$ it is doubtful that Bill Clinton will attempt to persuade the

85. See Berg, supra note 81.

86. In a speech to environmental groups to mark Earth Day, he committed the U.S. "to reducing our emissions of greenhouse gases to their 1990 levels by the year 2000." Richard L. Berke, Clinton Supports Two Major Steps for Environment, N.Y. TIMES, April 22, 1993, at A1.

87. Thomas F. Berg, Presidential Candidates Discuss Energy Issues, PuB. UTIL. ForT., Mar. 15, 1992, at 38 .

88. Debate is emerging within the Clinton Administration over the potential conflict between Clinton's economic policy goals and his campaign promise to freeze $\mathrm{CO}_{2}$ emissions at 1990 levels by the year 2000 . See Keith Schneider, Gore Meets Resistance in Effort for Steps on Global Warming, N.Y. TIMES, April 19, 1993, at A17. The permit-based GHG abatement regime outlined in Part III of this Note could help resolve the conflict between these two goals.

89. See supra note 86 . This level of abatement is also more aggressive than the plan advocated by Cline. See CLINE, supra notes 16-17 and accompanying text.

90. Alan S. Manne \& Richard G. Richels, $\mathrm{CO}_{2}$ Emission Limits: An Economic Costs Analysis for the USA, 11 ENERGY J. 51, 65, 68 (1990).

91. Nordhaus, supra note 12, at 930-33. But Nordhaus' analysis has been criticized for ignoring whole categories of potential damages. See Morgenstern, supra note 11, at 141-42.

92. GRUBB, supra note 36 , at $15-17$; see also Stone, supra note 49 , at 453 .

93. Gwen Ifil, The 1992 Campaign: The Democrats; Clinton, Gazing Beyond Nov. 3, Outlines Vision, N.Y. TIMES, Oct. 28, 1992, at A1; Doyle McManus, After the Cold War, What is Security?; As Issues of 
American public to make such a sacrifice. Yet nations throughout the world, whether industrialized or developing, would chafe at the idea of making economic transfers to the U.S., a major cause of the problem through its past and present industrial activity and extravagant use of resources. The U.S. position is thus distinguishable from that of LDC's, which threaten to contribute to the global warming problem in their effort to "catch up" to industrialized nations. Any resolution to the international deadlock on GHG abatement could thus significantly affect the distribution of global wealth and power, and herein perhaps lies a major obstacle to achieving international agreement. A successful international regime, then, would have to induce cooperation by allowing each nation to reap part of the benefit from GHG abatement. ${ }^{94}$

The next Part of this Note will propose that a market-based international tradeable emissions permit (TTEP) system could help fulfill this goal and resolve the negotiation deadlock by not only promoting efficient GHG abatement on a global scale, but also by providing a means for distributing the burden of GHG abatement equitably and flexibly. Each nation's eventual benefit under an ITEP system would likely equal or exceed its costs. Even if the U.S. does not enjoy a net economic gain under such a system, however, it would enjoy the political benefits of being an active participant in an international GHG abatement regime at minimal cost. ${ }^{95}$ U.S. participation would therefore help relieve the strain in relations with its European allies over the GHG abatement issue, ${ }^{96}$ improve relations with developing nations, and help secure the participation of the latter in a global GHG abatement regime. ${ }^{97}$

\section{MARKeT-BASED POLICY Options}

Several decades ago, market-based environmental regulation was a novel concept, but now it is hardly controversial to assert that market-based

Anti-Communism and Military Intervention Recede, the Focus is on Economic Strength, L.A. TIMES, Oct. 17, 1992, at A1.

94. One could argue that nations in a Cooperator's Loss could be induced to cooperate not only by making transfers of wealth, but by threatening punitive action if they do not cooperate. Such a method would only work, however, if there were just a few weak nations that could be isolated by the world such that the penaity threat was credible. Given the powerful economic and political position of the U.S., and the potential for a Cooperator's Loss in other world powers such as China, see Sebenius, supra note 34 , at 79 , and the reluctance of oil-producing nations to join an international accord that would threaten their main export, see Rio Conference, supra note 1, at 207, it appears unlikely that the threat of sanctions would be sufficiently credible to bring all of the potential noncooperators into line.

95. See Lakshman D. Guruswamy, Global Warming: Integrating U.S. and International Law, 32 ARIZ. L. REV. 221, 265 (1990).

96. See CLINE, supra note 8, at 324-25; When to Act on Climate Change: The Debate Continues as Action Begins, Global EnvTl. CHANGE REP., Aug. 14, 1992, available in LEXIS, Nexis Library, ZEV1 File.

97. See GRUBB, supra note 36 , at 24. 
approaches can lead to more effective environmental regulation at less cost than command-and-control approaches. ${ }^{98}$ Choosing between available market mechanisms, however, has led to significant disagreement. In the GHG abatement context there is no consensus. ${ }^{99}$ The two primary market mechanisms suggested for limiting GHG emissions are carbon taxes and tradeable carbon permits. ${ }^{100}$ The former method involves charging for each unit of emissions at a level that ideally matches the harm caused by that unit. The latter involves determining the overall efficient quantity of emissions, then allocating (or auctioning) emissions permits, which may be traded or sold between industries or nations.

This Part proposes that in light of the Cooperator's Loss problem outlined above, an international tradeable emissions permit (ITEP) system would be the preferable market-based approach. Because the ITEP system enables each nation to realize a gain from abatement activity by providing the easiest means of allocating and re-allocating GHG abatement costs, it helps resolve the Cooperator's Loss described in Part II. Moreover, an analysis of the characteristics of the global warming cost-benefit curves shows that the ITEP system is a more efficient means of GHG abatement than market-based fees or taxes.

\section{A. Implementing Tradeable Permits to Resolve the Cooperator's Loss}

\section{The ITEP System's Superiority to Taxes in Making Transfers Required to Resolve the Cooperator's Loss}

As discussed above, a successful international GHG abatement regime would make transfers back to nations whose costs of abatement exceed their individual benefits. ${ }^{101}$ Because a tax system would require outright transfers of wealth between nations while the ITEP system could achieve the wealth

98. See, e.g., Robert W. Hahn \& Robert N. Stavins, Incentive-Based Environmental Regulation: A New Era for an Old Idea?, 18 ECOLOGY L.Q. 1 (1991); Marchant, supra note 34, at 629-30; Robert N. Stavins \& Bradley W. Whitehead, The Greening of America's Taxes: Pollution Charges and Environmental Protection, 13 PROGRESSIVE POL'Y INST. REP. 7 (1992); Stewart, supra note 4, at 2093-97. In general, command-and-control approaches require specific procedures or technologies to be applied, such as the scrubbers that industries were required to install to remove sulfur dioxide from emissions under the 1977 Clean Air Act. See Marchant, supra note 34, at 629 \& n.21. Market-based approaches set a standard or a fee but allow industries to determine the most cost-effective means of compliance. Id.

99. Compare CLINE, supra note 8 , at 369-70 and Stavins \& Whitehead, supra note 98 , at 17-20 (advocating tax or fee-based systems) with GRUBB, supra note 36, at 41, Marchant, supra note 34, at 63135, and Stewart \& Wiener, supra note 53, at 106-08 (advocating permit systems).

100. Marchant, supra note 34, at 628-29; Stavins \& Whitehead, supra note 98, at 6; Stewart, supra note 4, at 2094; see also EPSTEIN \& GUPTA, supra note 22, at 14 (concluding that while there are other possible regimes for limiting GHG emissions, only tax and marketable permits can maximize economic efficiency of GHG abatement by "equalizing" marginal costs across abatement activities).

101. See supra notes $40-49,72$ and accompanying text. 
transfer through the allocation of permits itself, the ITEP system is better suited to resolving the Cooperator's Loss than a tax system. ${ }^{102}$

A tax system that maximizes the marginal efficiencies of international action would have to impose the same level of taxes on industry throughout the world. ${ }^{103}$ However, if a uniform tax were imposed on an international scale, industries in LDC's would be likely to suffer more than those in developed nations, because the latter have greater access to green technologies and because differences in levels of national wealth would make a moderate tax in developed nations seem exorbitant in LDC's. ${ }^{104}$ Since LDC's are among those nations likely to find themselves in a Cooperator's Loss, a tax system would only exacerbate the Cooperator's Loss problem by favoring developed nations. The Cooperator's Loss could then be resolved only through direct transfers of resources or revenue from developed nations to LDC's-an unwieldy, ad hoc solution to the problem.

In contrast, an ITEP system would resolve the Cooperator's Loss through the distribution of permits itself while still limiting emissions to an efficient level. ${ }^{105}$ After international policymakers set a quantity level for global GHG emissions, as they must under a permit system, the permits could be allocated to account for the Cooperator's Loss. In other words, a relatively large number of permits would be allocated to those nations facing the "loser's" preferences under a Cooperator's Loss. Because the permits would be saleable or leasable on an international scale, an allocation of permits favoring LDC's (or any other nations facing "loser's" preferences) would not lead to the inefficiencies caused by a tax system favoring certain nations. ${ }^{106}$ No matter what the initial allocation, industries throughout the world would buy, sell, and lease permits until there is a globally efficient distribution of permits.

In addition, developing nations would have incentives to purchase green technologies from industrialized countries in order to reduce their total GHG emissions level because they could then sell their excess permits in an

102. The ITEP system is also more efficient than the tax system in the GHG abatement context, as will be argued below. See infra text accompanying notes 127-142.

103. To understand why the tax level would have to be internationally uniform, suppose that international policymakers determine that the efficient tax is $\$ 100$ per ton of carbon emitted, a rate suggested by various economists. CLINE, supra note 8 , at 373 ; Stavins \& Whitehead, supra note 98 , at 18 19. If a tax of only $\$ 75$ per ton were imposed on LDC's because they faced the "loser's" preferences in a Cooperator's Loss, the industries in those nations would continue to emit GHG's until the marginal benefit of an additional unit of emissions were less than $\$ 75$ per ton. All the emissions that provided a marginal benefit to these industries between $\$ 75$ and $\$ 100$ per ton would be inefficient, as the cost imposed on society from the emissions would be $\$ 100$ per ton. A uniform international tax, set at the level of harm caused by GHG emissions, would thus be required to maximize the efficiency of an abatement regime.

104. See infra note 148 and accompanying text.

105. Cf. BRUCE A. ACKerman ET AL., THE UNCERTAIN SEARCh For ENVIRONMENTAL Quality 270 73 (1974) (outlining distributional and efficiency-enhancing benefits of a permit system over a tax system in context of water pollution controi).

106. See supra note 103. 
international tradeable emissions permit market. ${ }^{107}$ Industries in developed nations that would want to encourage such sale of permits might provide favorable terms for technology transfer to industries in LDC's, or might arrange to provide green technology directly in exchange for emissions permits. In this way, an ITEP system would facilitate an exchange of green technology that would both benefit industries in developed nations by making more permits available on the international market, while promoting "clean" industrialization and providing a source of revenue for developing countries. ${ }^{108}$ The development of global markets for green technologies, which would be fostered by their implementation in developing nations, could provide the U.S. with additional economic benefits to help offset any potential Cooperator's Loss it faces. ${ }^{109}$

\section{Allocating Permits to Resolve the Cooperator's Loss}

An initial allocation of permits among nations based in part on population would favor most developing nations, ${ }^{110}$ thereby helping to resolve their Cooperator's Loss. Allocation on the basis of population also fulfills Cline's "one person, one emissions vote" principle ${ }^{111}$ in distributing rights to the atmosphere, a global good. ${ }^{112}$ Given that the environment and the atmosphere are global goods to which each person in the world arguably has an equal right, it is both logical and equitable that each person in the world should receive an equal entitlement to these goods.

However, allocation based strictly on population would not resolve the Cooperator's Loss for nations like the U.S., whose share of the world's GHG emissions greatly exceeds its share of the world's population. ${ }^{113}$ In order to resolve the Cooperator's Loss for both the U.S. and LDC's while promoting an equitable distribution of permits, the allocation of permits should also be based on expected national net benefits from GHG abatement. More permits should be allocated to nations that expect fewer net benefits from abatement

107. For example, a green technology developed in an industrialized nation may be especially wellsuited to cutting emissions at inefficient LDC factories. The cost of purchasing the intellectual property rights and equipment necessary to develop the technology might be $\$ 12$ million, while the value on the international market of the corresponding emissions permits freed up by the technology might be $\$ 20$ million. The green technology might make it efficient for the LDC industry to engage in more industrial activity, using some of its own "freed up" permits; but excess permits would probably still be available for sale to industries in other nations.

108. The ITEP system could therefore help provide the mechanism for LDC's to "'leapfrog' directly to more advanced and efficient technologies," which Grubb identified as a "fundamental issue" for a successful GHG abatement regime. See GRUBB, supra note 36, at 24.

109. See Stewart, supra note 4, at 2104.

110. See EPSTEIN \& GUPTA, supra note 22, at 14. Allocation based in part on population at a fixed time-for example, 1990-would benefit developing nations in the initial allocation of permits while encouraging efforts to control future population growth. See CliNE, supra note 8, at 354 n.24.

111. CLINE, supra note 8, at 353 .

112. Sebenius, supra note 34 , at 73 .

113. See supra text accompanying note 81 . 
so that some of the gain from abatement action is transferred back to these nations to induce their participation in an international regime. Expected net benefit may be calculated in part based on historical GHG emissions, as more extensive abatement efforts will be necessary in nations with a historical dependence upon GHG-emitting technologies. ${ }^{114}$ But potential future emissions are another important aspect of expected net benefits; nations that forgo development of carbon-emitting fuel sources endure costs that are as real as costs endured by nations that must stabilize or reduce their historically high level of emissions. ${ }^{15}$ These lost future benefits should also be factored into the "net benefits from GHG abatement" calculation.

Although Cline advocates taxes over permits, ${ }^{116}$ he proposes that "if . . . taxes fail to achieve progress toward global emissions targets," permits could be allocated on the basis of GDP and historical GHG use, along with population. ${ }^{17}$ He suggests that each of these three factors could be weighted to establish both an equitable and politically acceptable international allocation of permits. ${ }^{118}$ This Note's conclusion that national expected net benefits should be a primary basis for allocation suggests that Cline's formula should be altered: GDP should not be included in the allocations equation, since GDP bears no relation to expected net benefit from GHG abatement, ${ }^{119}$ while potential future emissions should be added to the equation.

In short, a weighted consideration of population, historical GHG emissions, and potential future emissions would lead to an allocation of permits that would be both equitable-distributing benefits of GHG abatement worldwide-and practical-resolving the Cooperator's Loss and hence facilitating international agreement. ${ }^{120}$ Assuming all three factors are weighed

114. The inclusion of historical emissions in allocating permits would thus help resolve the Cooperator's Loss position of the U.S.

115. For example, nations such as China may lose the potential benefits of their GHG-intensive energy sources by participating in a GHG abatement regime.

116. See infra notes 143-153 and accompanying text (outlining and refuting Cline's reasoning for preferring taxes over permits).

117. CLINE, supra note 8 , at $352-53$.

118. Id. at 353-54.

119. Indeed, on the basis of the above argument that rich nations might value the benefits of GHG abatement more highly than poor nations, supra note 57 , high GDP nations should receive fewer permits than low GDP nations, not more permits as Cline's formula suggests. See CLINE, supra note 8, at 353-54. It might be argued in response that greater allocation on the basis of GDP is equitable since it would provide more permits where actual national productive output is higher. But permits allocated on this basis would only serve to reinforce the status quo; rich nations would receive more permits on the basis of their wealth, thereby entitling them to pollute more and become richer, while poor nations would receive few permits, thereby stifling future economic growth.

120. Borrowing Cline's notation but modifying his equation in light of the above discussion, the final allocations equation would be $Q_{j}=Q_{g}\left[W_{h} S_{h}+W_{f} S_{f}+W_{p} S_{p}\right]$, where $Q$ is the emissions quota, $i$ is the individual nation in question, $g$ is the world as a whole, $w$ represents the weight assigned to particular variable, $S$ represents nation $i$ 's share in the global total, and subscripts $h, f$, and $p$ represent nation $i$ 's historical use, future expected use, and population, respectively. Variables $h$ and $p$ should be measured at a baseline time, so as to provide the proper incentives for population reduction and decrease in GHG use, while variable $f$ can be adjusted over time in accordance with informational gains. See CLINE, supra note 8 , at 353 . 
equally, the U.S. would receive $14 \%$ of the world's permits, ${ }^{121}$ and China would receive $17 \% .{ }^{122}$

\section{B. Carbon Taxes Versus Carbon Permits: Economic Efficiency of Abatement Policy Instruments}

This Section argues that an ITEP regime is likely to be more economically efficient than a tax system in the GHG abatement context. This argument is not wholly separate from the discussion in the previous Section, but rather an extension of it, for the economic efficiency of the tradeable emissions permit scheme itself promotes international agreement. Nations are likely to find an economically efficient scheme less costly and hence more attractive. Indeed, the method of policy implementation may make the difference between a regime in which the theoretical gains of abatement may actually be realized and one in which the costs of abatement in fact exceed the benefits simply because of an inherently inefficient policy instrument. ${ }^{123}$

In theory, market-based tax and permit systems have exactly the same effect: setting the tax at the marginal cost of emissions would lead to the efficient quantity of emissions, while setting the quantity of emissions at the efficient level would lead to a price increase equal to the efficient tax. ${ }^{124}$ In practice, however, when there are uncertainties about the ideally efficient levels of control, the steepness (slope) of the marginal cost and marginal benefit curves may determine whether a tax or a permit system is preferable. ${ }^{125}$

As a general rule, given uncertainty about the placement of the marginal cost curve, permits are more appropriate when the marginal benefit curve (reflecting the marginal level of harm from emissions) ${ }^{126}$ is steep, and the marginal cost curve for controlling emissions is flat. ${ }^{127}$ In contrast, taxes are

121. This figure is based on the U.S.' $4.8 \%$ share of the world's population, CLINE, supra note 8 , at 330 tbl. 8.1, its $25 \%$ share of the world's emissions, GRUBB, supra note 36 , at 15-16, and its expected $12 \%$ share of world emissions in the year 2100, CLINE, supra note 8, at 337 tbl. 8.3.

122. This figure is based on China's $21.4 \%$ share of the world's population, CLINE, supra note 8 , at 330 tbl. 8.1, its $12 \%$ share of the world's emissions, GRUBB, supra note 36 , at 15 , and its expected $18 \%$ share of the world's emissions in the year 2100, CLINE, supra note 8, at 337 tbl. 8.3.

123. See Stewart, supra note 4 , at 2069.

124. See Cline, supra note 8, at 351; EPSTEIN \& GuPTA, supra note 22, at 15; William D. NoRdhaus, STRATEgIES FOR THE CONTROL OF CARbon DIOXIDE 25 (Cowles Foundation for Research in Economics at Yale University Discussion Paper No. 443, 1977); Stewart \& Wiener, supra note 53, at 110.

125. As noted above, moreover, practical differences between the two systems affect the costs of implementation. See supra text accompanying notes 102-109.

126. Note that the marginal level of harm from emissions is the same as the marginal benefit of abating emissions.

127. In other words, if each additional unit of GHG emissions causes increasingly severe levels of damage, the quantity-setting aspect of a permit system would help ensure that dangerous levels of harm are avoided. Zvi Adar \& James M. Griffin, Uncertainty and the Choice of Pollution Control Instrument, 3 J. ENVT'L ECON. \& MGMT. 178, 184, 188 (1976); see EPSTEIN \& GUPTA, supra note 22, at 15; Hahn \& Stavins, supra note 98, at 8-10; Stavins \& Whitehead, supra note 98, at 34. See generally Martin L. Weitzman, Prices vs. Quantities, 41 REV. ECON. STUD. 477 (1974) (pointing out comparative advantage of quantity instruments over price instruments when either benefit function is more sharply curved or cost 
preferable when the marginal cost curve rises steeply while the marginal benefit of abatement curve remains relatively flat. ${ }^{128}$ Economists Cline and Nordhaus have tried to make predictions about the steepness of marginal cost and marginal benefit curves, but their predictions differ, as will be illustrated below. Given the uncertainty that still prevails about placement of the marginal cost curve, these economists' differing predictions about the steepness of the marginal cost and benefit curves have important implications for choosing between tax and permit systems.

\section{Applying Cost-Benefit Curve Analysis to the Nordhaus Model}

Applying the cost-benefit curve analysis outlined above to Nordhaus' economic assessment of the costs and benefits of GHG abatement indicates that an international GHG abatement regime should be either primarily or exclusively a permit system. Figure 6-A is based on Nordhaus' sketch of the marginal costs of GHG reductions and the marginal damage from GHG emissions. ${ }^{129}$ The slope of the marginal cost of abatement curve varies in accordance with Nordhaus' conclusion that the first $10 \%$ of GHG emissions can be reduced at low cost, while the marginal cost of abatement rises sharply above that level. ${ }^{130}$ The two damage curves reflect the wide range in Nordhaus' own estimate about the level of damage to be expected from greenhouse warming. ${ }^{131}$ Marginal Damage Curve I represents a low-level estimate: the efficient level of reduction is below the $10 \%$ threshold, and hence on the flatter part of the marginal cost curve. In a world of perfect predictive ability, an efficient ITEP system would set the total level of GHG emissions reduction at $\mathrm{Q}_{\mathrm{E}}$, while an efficient tax system would set the price of GHG emissions at $P_{E}$, where the actual marginal cost curve and the marginal damage curve intersect (that is, where marginal cost equals marginal benefit). ${ }^{132}$

In the real world there is potential for error in estimating efficient emissions or tax levels. The broken curve reflects the marginal cost of abatement curve that policy analysts might hypothesize, given limited

function is more horizontal).

128. Thus, if the cost of abating greenhouse warming rises with increasing rapidity as more abatement is undertaken, the price-setting characteristic of a tax system would ensure that extremely expensive levels of abatement are avoided. CLINE, supra note 8, at 348; Adar \& Griffin, supra note 127, at 188.

129. Nordhaus, supra note 12 , at 924.

130. Id. at 936; see also Nordhaus, supra note 6 , at $40-41$ \& fig. 1 .

131. Id. at 933 (estimating that overall damage from a $3^{\circ} \mathrm{C}$ warming could be $1-2 \%$ of total global income, but acknowledging the ad hoc nature of this estimate). I have also drawn the marginal damage curves neither steep nor fiat, since Nordhaus says little is known about the shape of these curves. Id. at 923 . The slope I have given them is roughly the same as the slope Nordhaus gives his marginal damage curve, which he draws as a "wavy line" to reflect uncertainty. Id. at 923-24.

132. In such a world, it would not matter whether policymakers chose a permit or a tax system, because both would lead to the same efficient result. 


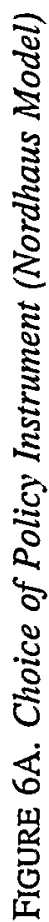

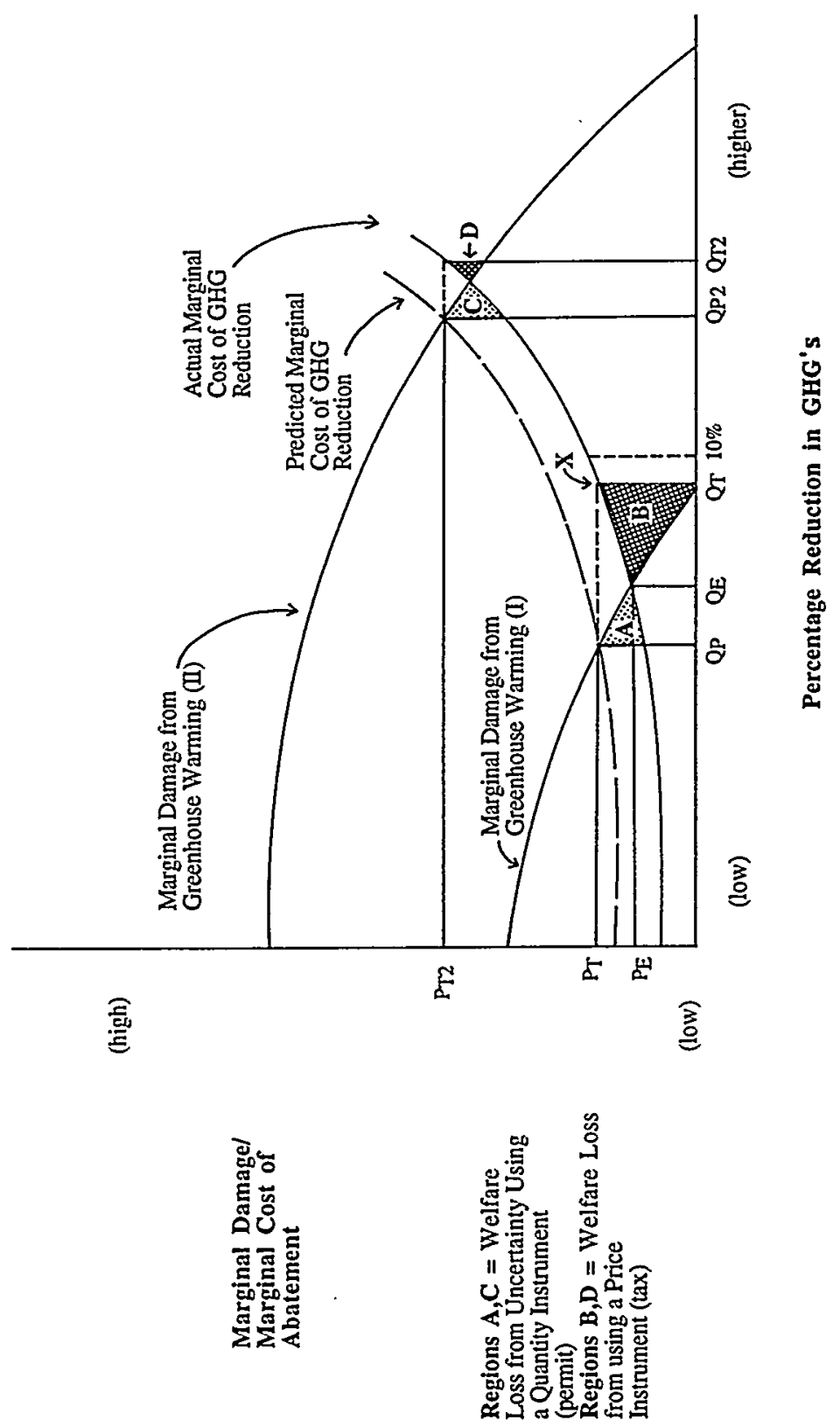


information and predictive capacities (i.e., uncertainty). ${ }^{133}$ As a result, they would set the level of emissions reduction at $Q_{P}$ in an ITEP system, where they believe the marginal cost and marginal damage curves intersect. Because the level of emissions reduction would be set lower than the perfectly efficient level, society's net loss due to uncertainty would be the area below the marginal damage curve and above the actual marginal cost curve between $Q_{P}$ and $\mathrm{Q}_{\mathrm{E}}$. Hence, if the ITEP system is employed, the loss to society from uncertainty would be the small lightly shaded region $(A) .^{134}$

If a tax system is used with the same predicted marginal cost curve, the policymakers would set the price of emissions at $\mathrm{P}_{\mathrm{T}}$, again where they believe marginal cost is equal to marginal benefit. The actual level of emissions reduction, however, would be where the set price, $\mathrm{P}_{\mathrm{T}}$, intersects the actual marginal cost curve, at point $\mathrm{X}$, leading to a level of emissions reduction at point $\mathrm{Q}_{\mathrm{T}}$. The resulting loss of welfare to society due to uncertainty would be the area between the marginal cost and marginal damage curves, the heavily shaded region $(B)$.

As the graph indicates, an ITEP system results in a lower net welfare loss to society than a tax system when there are informational and predictive limitations about actual marginal costs. ${ }^{135}$ This conclusion is consistent with the analysis in Section $\Pi 1(\mathrm{~B})$, suggesting that a permit system is preferable when marginal costs are relatively flat.

Indeed, this conclusion holds only for the portion of Nordhaus' marginal cost curve below the $10 \%$ level of GHG reduction, where marginal costs rise gradually. When the same analysis is carried out on Damage Curve II, which intersects the marginal cost curve at its steeper portion, a tax system becomes preferable. In that higher damage scenario, a tax system leads to a lower net welfare loss to society (heavily shaded region $D$ ) than an ITEP system (lightly shaded region $C$ ). This conclusion is consistent with the analysis in Section III(B) that a tax system is preferable when marginal costs are steep.

Thus, Nordhaus' GHG abatement cost and benefit functions suggest that an international regime should allocate permits up to the $10 \%$ level of abatement and impose a tax above that level. Based on Nordhaus' conclusion that the most efficient level of abatement is $11 \%$, an international regime

133. For the sake of clarity, the graph shows uncertainty going in only one direction, i.e., above the actual marginal cost curve. In the real world, uncertainty could go in both directions-either above or below the actual marginal cost curve-and the results would be symmetric on either side of the cost curve.

134. Even though there is a slight loss due to uncertainty about the placement of the marginal cost curve, the graph still reflects a net benefit to society from abatement action. The net benefit is represented by the area above the actual marginal cost curve and below the marginal damage curve up to point $\mathrm{Q}_{\mathrm{p}}$.

135. Region $B$, representing the welfare loss to society from uncertainty under a tax system, is larger than region $A$, representing the welfare loss to society from uncertainty under a permit system. 


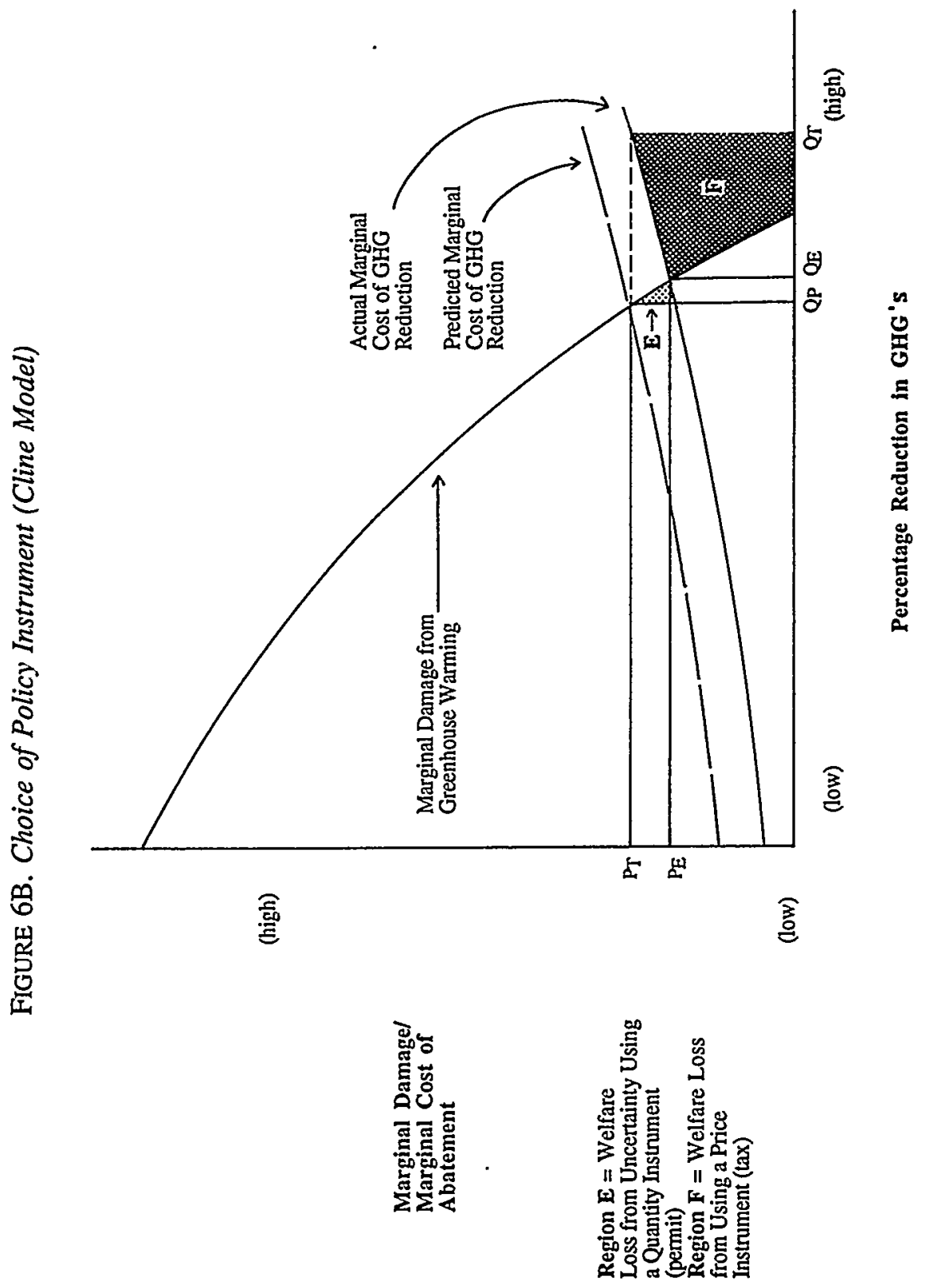


should thus be primarily permit-based, with only a minimal tax. ${ }^{136}$ Moreover, since Nordhaus' marginal cost curve does not reflect the potential marginal efficiencies of international action, ${ }^{137}$ the flat part of the marginal cost curve probably extends beyond the $10 \%$ level of abatement, making an ITEP system preferable over an even wider range of investment levels. If one takes account of these additional marginal efficiencies not considered by Nordhaus, an ITEP system alone would be likely to achieve an efficient level of GHG reduction.

\section{Applying Cost-Benefit Curve Analysis to the Cline Model}

Based on the shape of Cline's cost and benefit curves, an ITEP system would be preferable to a tax system. In contrast to Nordhaus, who expresses uncertainty about the shape of the marginal damage function, Cline asserts that greenhouse warming damage functions have exponents ranging from 1.3 to 2.0. ${ }^{138}$ Any damage exponent higher than 1.0 implies that marginal damages increase as emissions increase; hence the marginal damage curve increases with increasing levels of emissions. ${ }^{139}$ Moreover, Cline's GHG abatement cost functions are essentially linear, and have "gentler slopes" in the long term on the assumption that technological improvements will make abatement efforts less costly. ${ }^{140}$ Furthermore, Cline estimates that the first $20 \%$ of GHG emissions reduction could take place at very low cost, in contrast to Nordhaus' $10 \%$ estimate. ${ }^{141}$ Figure 6-B is based on Cline's description of the damage and cost functions in the long term. ${ }^{142}$

Again, assuming that policymakers lack perfect information and their predicted marginal cost curve differs from the actual marginal cost curve, they will set total emissions reduction at $Q_{P}$ (rather than $Q_{E}$, the truly efficient level)

136. Nonetheless, Nordhaus argues that a carbon tax would be preferable because it would generate revenue for the government and the public, rather than just transferring revenue between industries, which he calls the "scam" of the CFC tradeable emissions program. Interview with William D. Nordhaus, Professor of Economics, Yale University, in New Haven, Conn. (Nov. 23, 1992). Under the CFC tradeable emissions program, the government distributed a limited number of permits to industry at no charge. Such gratuitous distribution of permits, however, is not an inherent feature of a permit system. Tradeable permits auctioned to industry would generate revenue for the government. See Stavins \& Whitehead, supra note 98, at 34. An auction would ensure that the price of permits is set at an efficient market rate. Indeed, if permits are leased by the government at auctioned rates, they could provide as stable and regular a source of revenue as taxes. The advantages of an auction-lease system over a simple auction system are discussed infra notes 156-157 and accompanying text.

137. See supra text accompanying notes $31-32$ (pointing out that Nordhaus' cost data is based only on the U.S.).

138. Cline, supra note 8, at 292.

139. Id. Cline points out, for example, that coastal flooding and land loss from the melting of glaciers and ice sheets would occur with increasing severity at higher levels of global warming. Id. at 107-10, especially 109-110. Because Cline analyzes a longer period than Nordhaus and uses a relatively low discount rate, the potential impact of his geometric damage curve is heightened.

140. Id. at 198-99 \& fig. 5.1, 228, 232.

141. Id. at $228,232$.

142. The sketch as such does not appear in Cline, but is based on his descriptions of the cost and damage functions. See supra notes 138-141 and accompanying text. 
in an ITEP system. The resulting welfare loss would be the lightly shaded region $(E)$, between the marginal damage and actual marginal cost curves. In contrast, if policymakers implement a tax system on the basis of their predicted marginal cost curve, they will set a tax on emissions at $P_{T}$, with a resulting level of emissions reduction at $\mathrm{Q}_{\mathrm{T}}$ (where the set price intersects the actual marginal cost curve). The welfare loss under such a tax system is represented by the heavily shaded region $(F)$, the area between the actual marginal cost curve and the marginal damage curve. Consistent with the analysis in Section III(B), an ITEP system is more efficient than a tax system in the Cline model since marginal costs increase gradually while marginal damages increase sharply with increasing levels of GHG warming.

While Cline notes in passing that an analysis of the steepness of cost and benefit curves might lead to preference for a "quota" (permit) system over a tax system in the global warming context, ${ }^{143}$ he nonetheless recommends taxes for several reasons. First, Cline argues that one can easily readjust taxes if they lead to inefficient levels of emissions. ${ }^{144}$ However, this point begs the question; the only way policymakers can know whether the level of emissions under a tax system is inefficient is if there is no uncertainty about the marginal cost and marginal damage curves. In such a world of perfect information, both a tax system and an ITEP system would lead to the perfectly efficient outcome, and there would be no preference for one over the other. ${ }^{145}$ The relevant inquiry, then, is which system is preferable given the uncertainties that policymakers face. ${ }^{146}$

Second, Cline asserts that because permits would require an initial allocation determination that would be extremely difficult to negotiate, a tax would be preferable in the short term. Taxes, he argues, "would be blind with respect to individual countries and parties." ${ }^{147}$ Yet his analysis on this point is also flawed. While it is true that negotiating the initial allocation of permits would be difficult, an international unit tax for emissions is infeasible. Industries in developing countries have less advanced technologies for reducing

143. CliNe, supra note 8 , at 350 .

144. Id.

145. See supra note 124 and accompanying text.

146. Moreover, if policymakers gain additional information, the level of permits could be readjusted under a permit system almost as easily as a tax is readjusted: the government could buy back permits from industry when the costs of controlling emissions fall, or could decide not to re-lease some permits after a lease period expires. If the government auctioned the permits to industry in the first place in order to raise revenue rather than distributing them at no cost, it should not be burdensome for the government to buy some permits back from industry. See Stavins \& Whitehead, supra note 98 , at 34 (pointing out that permits could be auctioned by government to raise revenue). Indeed, government acting in the public interest would generally want to purchase permits back from industry just after the price of permits has fallen in response to some development, such as a technological advance, that lowers the costs of controlling emissions, and hence lowers the efficient level of emissions. The burden on government coffers, therefore, should not be severe, since the government will generally have sold the permits at a higher price than it must pay to repurchase them.

147. Cline, supra note 8 , at 351. 
GHG emissions, ${ }^{148}$ which would make the tax most burdensome per unit of industrial output in nations that could least afford it. Even disregarding the differences in technology, a tax which an industry in a developed nation could easily bear would be devastating to an industry in a developing nation. ${ }^{149} \mathrm{~A}$ budding industry in China or India, for example, simply could not afford to pay a per unit tax that equalled a per unit tax set in the U.S. ${ }^{150}$

Cline is correct that countries could not negotiate an international allocation of permits in the short term. But it makes sense to begin working toward negotiating an ITEP system, since an international tax would be no easier to negotiate, while the ITEP system is better suited to the economics of global warming. ${ }^{151}$ The first step toward such an international regime could be implementing tradeable emissions permit systems on the domestic level. ${ }^{152}$ Nations that have already committed themselves to GHG reduction or stabilization ${ }^{153}$ would benefit from such a system's efficiencies while they promote the planning and negotiation of an even more efficient international tradeable emissions permit regime. Domestic implementation of tradeable emissions permit systems would also provide a model to the rest of the world for efficient GHG reduction, thereby facilitating negotiation of an international system.

\section{Applying the Permit System to the Cooperator's Loss Game}

The previous two Sections demonstrated that an ITEP system would provide an equitable and efficient basis for resolving the Cooperator's Loss. An initial, front-end distribution of permits, however, would modify the choice matrix presented in Figure 4. Using the figures set out in Part II, and assuming a transfer of $\$ 2 \mathrm{~B}$ to the developing world through skewed distribution of permits, Figure 7 illustrates the situation immediately after the permit allocation. Because the distribution of permits occurs on the front end, the Third World receives $\$ 2 \mathrm{~B}$ in permits regardless of whether it cooperates in the GHG abatement scheme.

148. See GRUBB, supra note 36 , at 24 .

149. See supra text accompanying notes 103-104.

150. One might argue, in response, that different tax rates should be set in different nations to account for economic disparities. However, there are two problems with that option: first, the global efficiencies of achieving the greatest abatement at the lowest marginal cost would be lost, supra note 103; second, the obstacles to negotiating such variable tax rates on an international scale could be at least as great as the obstacles to negotiating an international allocation of permits.

151. See supra text accompanying notes 129-142.

152. During the campaign, Bill Clinton advocated such a domestic tradeable emissions permit system as one way to deal with the global warming problem. See supra note 87 and accompanying text. He promoted a carbon tax with equal enthusiasm, however, apparently unaware that a permit system would be more efficient than a tax system. Berg, supra note 87 , at 38 .

153. See supra note 83 and accompanying text. 
FIGURE 7. The LDC Cooperator's Loss After Front-End Permit Transfer

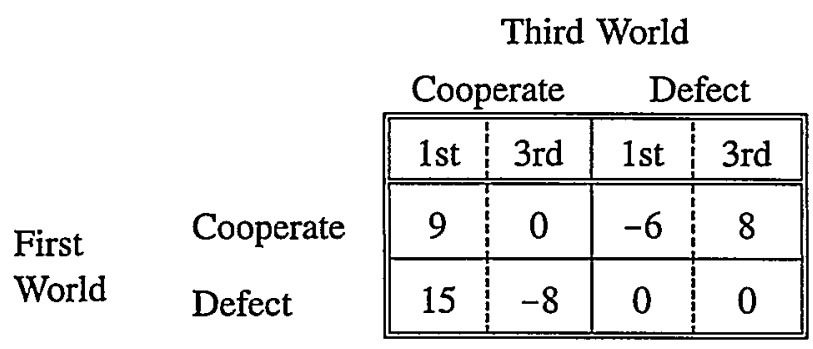

In Figure 7, both the northwest and the northeast quadrants, in which the First World cooperates, reflect the transfer of $\$ 2 \mathrm{~B}$ from the developed world to the developing world, whereas Figure 4 hypothesized that a transfer would be made only if the Third World cooperates. Since the ITEP system must allocate permits on the front end, there is no way to restrict the transfer to the total cooperation scenario. ${ }^{154}$

Nonetheless, the problem presented after the allocation of permits is still a traditional Prisoner's Dilemma, and the only difference between Figures 7 and 4 is that an international agreement must threaten a tariff of $\$ 8 \mathrm{~B}$ for Third-World noncooperation in Figure 7 (the ITEP system), whereas it need only threaten a tariff of $\$ 6 \mathrm{~B}$ for Third-World noncooperation in Figure 4. ${ }^{155}$ The final post-tariff result is precisely the same as in Figure 5 above.

Hence, an ITEP system with allocation of permits adjusted to induce cooperation and with penalty tariffs imposed against noncooperators would provide the most efficient and equitable regime for GHG abatement. Moreover, a leased ITEP system (with lease price determined by auction to maximize market efficiencies) would provide governments with a regular source of revenue, which they could use to offset reduction of inefficient taxes or for environmental cleanup. ${ }^{156}$ While the simple sale of permits would provide government revenue, governments might prefer leasing if they suspect that the price of permits will be highly volatile and they want to take advantage of possible future increases in their value. Leasing would also prevent one government or one industry in a nation from permanently selling its nation's

154. Since the First World is not cooperating in the southwest and southeast quadrants, no transfer is made in those scenarios.

155. Note that the "tariff" here has no relation to the discussion about taxes versus permits above. The tariffs imposed for noncooperation are penalties, and could take the form of trade sanctions on nations that refuse to participate in a GHG abatement regime. Such tariffs are actually unlikely to be imposed because the mere threat of their imposition should be sufficient to induce cooperation. The "taxes" discussed in Part III, in contrast, are not penalties but fees designed to make industries internalize the costs of their polluting activities. Part III concluded that permits would achieve this goal more efficiently than taxes in the global warming context. tax).

156. Cf. Stavins \& Whitehead, supra note 98 , at $15-16$ (suggesting such uses for a domestic carbon 
future rights to other nations, and would thus help prevent the problem of one government declaring invalid the actions of a predecessor government in the same nation. ${ }^{157}$ Finally, leasing permits might be preferable to selling them because leasing reduces the potential for a nation, a group of nations, or an industry coalition to buy up a large share of the permits and attain global oligopoly power or form a cartel. ${ }^{158}$

\section{CONCLUSION}

Despite scientific uncertainty and conflicting assumptions in economic models of GHG abatement, moderate to aggressive abatement measures are warranted to avert the potentially irreversible, catastrophic impact of global warming. The most effective and efficient abatement measures require worldwide cooperation both to overcome free riding and to exploit the marginal efficiencies involved in abating GHG's where doing so is cheapest. Even assuming that GHG abatement action is efficient and assuming international cooperation, certain nations may have more to lose under a GHG abatement regime than they would lose from unabated global warming. Developing nations and the U.S. probably believe they face such a Cooperator's Loss. Developing nations fear that losses from forgone industrialization would exceed the potential benefits they would receive from GHG abatement, while the U.S. fears it would be burdened with a huge share of the GHG abatement costs because of its dependence upon GHG-emitting technologies.

An ITEP regime could help resolve the Cooperator's Loss in three ways. First, it would promote abatement at the lowest possible cost by allowing nations to take advantage of marginal efficiencies on an international scale. Second, an ITEP system would prove more administrable and equitable than a tax system in resolving the Cooperator's Loss. In developing nations, taxes could be devastating. In contrast, permits distributed in part based on population might resolve the international negotiation deadlock by giving industries in developed nations the opportunity to obtain permits through purchase or trade, while providing developing nations with green technology and revenue. Finally, the ITEP system would minimize the welfare loss from uncertainty about the level of marginal costs. By equitably allocating emissions permits and facilitating the efficient reallocation of permits on an international market, the ITEP system could resolve the Cooperator's Loss and thereby avert the impending global warming crisis.

157. See GRUBB, supra note 36 , at 34 .

158. See Cline, supra note 8 , at 352. 